appeared before the pulmonary infection had completely cleared and was associated with probable histoplasma lymphadenitis. The only characteristic of meningitis caused by this organism appears to be the singular lack of meningeal irritation. The character of the cerebrospinal fluid is not specific, for although the sugar content is usually reduced the various authors have described counts of from 54 to 235 white cells per c.mm. and varying from $100 \%$ lymphocytes to $90 \%$ neutrophils. It is therefore quite possible that meningeal exudate was present in Case 2.

The protean nature of the neurological signs results from the scattered miliary granulomata that usually occur in the brain adjoining the meninges. Further support for the presence of a more severe and chronic histoplasmosis infection in Case 1 is given by the persistence of a positive histoplasmin complement-fixation test after nearly four years. This would be most unusual in an acute pulmonary infection which cleared radiologically in four months.

\section{Summary}

Pulmonary histoplasmosis occurring in two British subjects resident in Cyprus is reported for the first time from this locality.

The illness in both cases followed the visit to a cave where a bat was handled by both patients.

It is suggested that the subsequent encephalitis from which one of the patients made a spontaneous recovery was also due to infection by Histoplasma capsulatum.
I wish to thank Squadron-Leader M. J. Phillips for his helpful criticism of this paper, and the Director-General of the Royal Air Force Medical Services for permission to publish.

\section{REFERENCES}

Aspin, J., and di Bellard-Pietri, E. (1959). Transactions of the Cave Research Group of Great Britain, vol. 5, No. 2.

Bellin, E. L., Silva, M., and Lawyer, T. (1962). Neurology (Minneap.), 12, i 148.,

Campbell, C. C., Hill, G. B., and Falgout, B. T. (1962). Science, 136, 1050 .

Christie, A. (1958). Ann. intern. Med., 49, 544

Darling, S. T. (1906). F. Amer. med. Ass., 46, 1283.

- (1908). Arch. intern. Med., 2, 107.

Demonbreun, W. A. (1934). Amer. F. trop. Med., 14, 93.

Dodd, K., and Tompkins, E. H. (1934). Ibid., 14, 127.

Duarte, E. (1945). Mem. Inst. Osw. Cruz., 43, 457.

Edwards, P. Q., Geser, A. G., Kiølbye, E. H., Meijer, J., Christensen, O. W. (1956). Amer. F. trop. Med. Hyg., 5, 224. and Klær, J. H. (1956). Ibid., 5, 235.

Emmons, C. W. (1958). Publ. Hlth Rep. (WVash.), 73, 590

Juba, A. (1958). Psychiat. et Neurol. (Basel), 135, 260.

Lehan, P. H., and Furcolow, M. L. (1957). Y. chron. Dis., 5, 489.

Loosli, C. G. (1955). Med. Clin. N. Amer., 39, 171.

(1957). ¥. chron. Dis., 5, 473.

Murdock, W. T., Travis, R. E., Sutliff, W. D., and Ajello, L. (1962). J. Amer. med. Ass., 179, 73.

Nelson, J. D., Bates, R., and Pitchford, A. (1961). Amer. F. Dis. Child., $102,218$.

Prior, J. A., and Cole, C. R. (1951). Amer. Rev. Tuberc., 63, 538.

Quiroga, M. I., Copello, A. R., Magnin, P. H., and Somoza, M. J. (1962). Pren. méd. argent., 49, 1060.

Schulz, D. M. (1953). 7. Amer. med. Ass., 151, 549.

Shapiro, J. L., Lux, J. J., and Sprofkin, B. E. (1955). Amer. J. Path., 31, 319.

Sprofkin, B. E., Shapiro, J. L., and Lux, J. J. (1955). F. Neuropath. exp. Neurol., 14, 288.

\title{
Hormone Excretion Studies of Gynaecomastia of Puberty
}

\author{
J. W. JULL,* PH.D., B.SC.; J. A. DOSSETT, $†$ M.D.
}

Brit. med. F., 1964, 2, 795-797

Gynaecomastia in the male is an excessive mammary fibroepithelial proliferation presenting as a firm disk-like plaque beneath the nipple and areola. It may be bilateral or unilateral, and varies from small plaques just detectable by palpation to extensive structures comparable to the breasts of female adolescence. Practically without exception these epithelial proliferations of the male breast are found microscopically to be composed entirely of ducts. The frequent association of the condition with actively secreting tumours of the testis or adrenals, and the fact that similar hypertrophy follows exposure to oestrogen, either as an industrial hazard or therapeutically, has led to the assumption that gynaecomastia is the result of enhanced oestrogen levels in the body (Hall, 1959; Folley, 1960).

Some degree of gynaecomastia also occurs as a normal accompaniment of puberty in the majority of boys, when it is usually bilateral and persists for about 12 to 18 months (Hall, 1959). It has been generally assumed that pubertal gynaecomastia is due to the production of increased amounts of oestrogen, either concurrently with increase in androgen secretion or as a result of increased metabolic conversion from the elevated levels of androgen.

The following study was designed to investigate the hormonal factors concerned in the appearance of gynaecomastia

\footnotetext{
- Department of Experimental Pathology and Cancer Research, University of Leeds. Present address: Cancer Research Centre, University of British Columbia, Vancouver 8, Canada. † Department of Pathology, St. James's Hospital, Leeds.
}

of puberty, so as to evaluate the significance of the condition clinically and to gain further information concerning factors in the growth of the human breast generally. The plan was to investigate groups of boys before puberty, during puberty with and without gynaecomastia, and after puberty when the condition has regressed. It was expected that changes in oestrogen and 17-ketosteroid excretion might thus be related to the appearance and subsequent disappearance of mammary hypertrophy.

\section{Methods}

A Leeds boys' school was visited and co-operation obtained from boys aged between $10 \frac{1}{2}$ and 18 years. A medical history was taken and a physical examination made to assess development and exclude so far as possible those with a eunuchoid stature or a past or present disorder likely to be associated with gynaecomastia. The boys were classed as pre-pubertal, pubertal, or post-pubertal by examination of the size of the testes, the presence or absence of axillary, pubic, limb, and facial hair, acne, and the depth of the voice. The degree of sexual maturity was denoted by "immature," "partially mature," or "fully mature." Gynaecomastia was detected by the presence of a palpable disk beneath the nipple, the approximate size of which was noted.

Twenty-four boys, seven of whom had some degree of gynaecomastia, collected all their urine for three consecutive days. Daily specimens were stored at $4^{\circ} \mathrm{C}$., pooled for each 
subject at the end of the collection period, and then kept frozen at $-20^{\circ} \mathrm{C}$. while awaiting chemical estimations, which were made on the pooled specimens. All the boys collaborated enthusiastically, and we believe that in all cases collection of urine was as complete as possible.

Oestrogens (oestriol, oestrone, and oestradiol) were measured in quadruplicate on aliquots equivalent to one-third of the average daily volume by the method of Brown, Bulbrook, and Greenwood (1957), as applied by Jull, Shucksmith, and Bonser (1963); total 17-ketosteroids (17-KS) in duplicate by the method of Drekter, Heisler, Scism, Stern, Pearson, and McGavack (1952); fractionated 17-ketosteroids, on some urines only, by the method of Kellie and Wade (1957); 17ketogenic steroids (17-KGS) in duplicate by the method of Norymberski, Stubbs, and West (1953); and pregnanediol and pregnanetriol in duplicate by the method of Leon and Bulbrook (1960).

\section{Results}

The average daily excretions, over a three-day period, of the hormone metabolites measured are recorded in Tables I and II. When tabulated according to age the boys fall naturally into four groups: (A) immature without gynaecomastia; (B) partially or completely mature without gynaecomastia, aged 12-15 years ; (C) partially or completely mature with gynaecomastia, aged 12-15 years; and (D) completely mature without gynaecomastia.

The average daily 17-KS excretion showed little variation between individuals in group $\mathrm{A}$, with an average excretion of $2.2 \mathrm{mg}$. daily. In the pubertal groups $\mathrm{B}$ and $\mathrm{C}$ there were increased average levels of 3.7 and $5.0 \mathrm{mg}$. daily, with greater individual variation, consistent with the more mature physical development. Post-puberty, group $\mathrm{D}$, there was a further significant rise in excretion to values (average $10.1 \mathrm{mg}$. daily) characteristic, in our experience, of men generally. This increase was largely due to a greater excretion of androsterone and etiocholanolone (Table II). Excretion of 17-KGS increased slightly with advancing age and development in groups $A, B$, and $C$ and showed a relatively marked increase in the fully mature group $D$.

The total excretion of urinary oestrogens and the relative amounts of oestriol, oestrone, and oestradiol did not differ significantly in groups $\mathrm{A}, \mathrm{B}$, or $\mathrm{C}$ despite the marked variations in the degree of maturity and variations in other hormonal metabolites. In groups $\mathrm{B}$ and $\mathrm{C}$, where the age range was the same and the degree of maturity similar, there were no differences at all in oestrogen excretion, although gynaecomastia was present in all boys of group C. Oestrogen excretion by fully mature boys (group D) was much greater-average total $7.5 \mu \mathrm{g}$., as against averages of $1.8,2.9$, and $2.6 \mu \mathrm{g}$. in the younger boys. The apparent relative increase in the excretion of oestradiol in the older boys may not have been a real difference, but could have been due to the greater reliability of the chemical method at higher concentrations.

There were apparently greater levels of pregnanediol and pregnanetriol excretion after puberty, but the reality of these differences at low concentrations cannot be assessed from the present work.

\section{Discussion}

Our experience in the selection of boys for this study demonstrates the ease with which gynaecomastia of puberty might be studied more extensively. Our figures do not give an exact picture of the frequency of the condition, as we did not keep a check on the total numbers examined before we encountered sufficient volunteers with gynaecomastia. Our impression was that about half the boys in the age-group $12 \frac{1}{2}-14 \frac{1}{2}$ had some degree of mammary hypertrophy.

The results of the oestrogen studies show clearly that the development of pubertal gynaecomastia is not a result of increased oestrogen production, either directly or by metabolic conversion of androgens. Although only a fraction of the oestrogen excreted is accounted for by the urinary oestradiol, oestrone, and oestradiol, which were measured, nevertheless these metabolites reflected changes in the male after puberty, and it is well established, and accepted, that they reflect the

TABLE I.-Average Daily Urinary Excretion of Hormone Metabolites by Boys of Various Ages Estimated on Quadruplicate Aliquots of a Three-day Pool of Urine

\begin{tabular}{|c|c|c|c|c|c|c|c|c|c|c|c|c|c|}
\hline Group & \multirow{2}{*}{$\begin{array}{c}\begin{array}{c}\text { Subject } \\
\text { No. }\end{array} \\
1 \\
2 \\
3 \\
4 \\
5 \\
6\end{array}$} & \multirow{2}{*}{$\begin{array}{l}\text { Age* } \\
10.7 \\
10.9 \\
11.6 \\
11.8 \\
12.3 \\
12.6\end{array}$} & \multirow{2}{*}{$\begin{array}{c}\text { Sext } \\
\text { Devt. }\end{array}$} & \multirow{2}{*}{$\begin{array}{c}\begin{array}{c}\text { Gynaeco- } \\
\text { mastia }\end{array} \\
= \\
= \\
=\end{array}$} & $\begin{array}{c}\text { Oestriol } \\
\mu \mathrm{g} .\end{array}$ & $\begin{array}{c}\text { Oestrone } \\
\mu \mathrm{g} .\end{array}$ & $\begin{array}{c}\text { Oestradiol } \\
\mu \mathbf{g} .\end{array}$ & $\begin{array}{c}\text { Total } \\
\text { oestrogen } \\
\mu \mathrm{g} .\end{array}$ & $\begin{array}{l}\text { Pregnane- } \\
\text { diol } \\
\text { mg. }\end{array}$ & $\begin{array}{c}\text { Pregnane- } \\
\text { triol } \\
\text { mg. }\end{array}$ & $\begin{array}{c}\text { 17-KS } \\
\text { mg. }\end{array}$ & \multicolumn{2}{|c|}{$\begin{array}{c}\text { 17-KGS } \\
\text { mg. }\end{array}$} \\
\hline A \{ & & & & & $\left.\begin{array}{l}0.6 \\
1.0 \\
0.0 \\
0.8 \\
1.7 \\
0.5\end{array}\right\} 0.8$ & $\left.\begin{array}{l}1.3 \\
0.0 \\
1.6 \\
1.3 \\
0.6 \\
1.0\end{array}\right\} 0.9$ & $\left.\begin{array}{l}0.0 \\
0.0 \\
0.0 \\
0.0 \\
0.6 \\
0.0\end{array}\right\} 0.1$ & $\left.\begin{array}{l}1.9 \\
1.0 \\
1.6 \\
2.1 \\
2.9 \\
1.5\end{array}\right\} 1.8$ & $\left.\begin{array}{l}0.2 \\
0.2 \\
1.6 \\
0.2 \\
0.6 \\
0.2\end{array}\right\} 0.25$ & $\left.\begin{array}{l}0.1 \\
0.6 \\
0.2 \\
0.1 \\
0.3 \\
0.1\end{array}\right\} 0.23$ & $\left.\begin{array}{l}2 \cdot 3 \\
2 \cdot 8 \\
2 \cdot 0 \\
2 \cdot 2 \\
2 \cdot 0 \\
2 \cdot 0\end{array}\right\} 2 \cdot 26$ & $\left.\begin{array}{l}5 \cdot 9 \\
6 \cdot 9 \\
6 \cdot 3 \\
6 \cdot 5 \\
6 \cdot 7 \\
6 \cdot 1\end{array}\right\}$ & $6 \cdot 4$ \\
\hline $\mathbf{B}$ & $\begin{array}{r}7 \\
8 \\
9 \\
10 \\
11\end{array}$ & $\begin{array}{l}12 \cdot 10 \\
12 \cdot 11 \\
13 \cdot 1 \\
13 \cdot 4 \\
14.5\end{array}$ & $\begin{array}{l}2 \\
2 \\
2 \\
2 \\
3\end{array}$ & $\begin{array}{l}\overline{-} \\
\bar{z}\end{array}$ & $\left.\begin{array}{l}0.9 \\
1.5 \\
2.3 \\
2.5 \\
0.6\end{array}\right\} 1.6$ & $\left.\begin{array}{l}1.9 \\
1.7 \\
0.8 \\
1.0 \\
0.8\end{array}\right\} 1.2$ & $\left.\begin{array}{l}0.0 \\
0.0 \\
0.0 \\
0.3 \\
0.0\end{array}\right\} 0.1$ & $\left.\begin{array}{l}2.8 \\
3.2 \\
3.1 \\
3.8 \\
1.5\end{array}\right\} 2.9$ & $\left.\begin{array}{l}0.1 \\
0.3 \\
0.3 \\
0.2 \\
0.3\end{array}\right\} 0.24$ & $\left.\begin{array}{l}0.1 \\
0.2 \\
0.3 \\
0.2 \\
0.2\end{array}\right\} 0.20$ & $\left.\begin{array}{l}2 \cdot 7 \\
4 \cdot 3 \\
5 \cdot 0 \\
3 \cdot 8 \\
2 \cdot 9\end{array}\right\} 3 \cdot 7$ & $\left.\begin{array}{l}7 \cdot 1 \\
8 \cdot 1 \\
9 \cdot 4 \\
7 \cdot 0 \\
6 \cdot 3\end{array}\right\}$ & $7 \cdot 6$ \\
\hline C & $\begin{array}{l}12 \\
13 \\
14 \\
15 \\
16 \\
17 \\
18\end{array}$ & $\begin{array}{l}12 \cdot 7 \\
12 \cdot 10 \\
12 \cdot 10 \\
13 \cdot 3 \\
13 \cdot 3 \\
13 \cdot 8 \\
14 \cdot 1\end{array}$ & $\begin{array}{l}2 \\
3 \\
2 \\
2 \\
3 \\
3 \\
2\end{array}$ & $\begin{array}{c}+ \\
+++ \\
+++ \\
++ \\
++ \\
++ \\
++\end{array}$ & $\left.\begin{array}{l}2.8 \\
1.7 \\
0.4 \\
1.7 \\
1.6 \\
2.5 \\
1.3\end{array}\right\} 1.7$ & $\left.\begin{array}{l}0.0 \\
0.8 \\
0.4 \\
1.0 \\
1.5 \\
0.8 \\
0.8\end{array}\right\} 0.8$ & $\left.\begin{array}{l}0.0 \\
0.0 \\
0.0 \\
0.0 \\
0.0 \\
0.6 \\
0.0\end{array}\right\} 0.1$ & $\left.\begin{array}{l}2.8 \\
2.5 \\
0.8 \\
2.7 \\
3.1 \\
3.9 \\
2.1\end{array}\right\} 2.6$ & $\left.\begin{array}{l}0.4 \\
0.5 \\
0.4 \\
0.3 \\
0.4 \\
0.3 \\
0.3\end{array}\right\} 0.37$ & $\left.\begin{array}{l}\overline{0.3} \\
0.4 \\
0.2 \\
0.3 \\
0.3 \\
0.3\end{array}\right\} 0.30$ & $\left.\begin{array}{l}4 \cdot 7 \\
5 \cdot 3 \\
5 \cdot 0 \\
2 \cdot 9 \\
5 \cdot 6 \\
4 \cdot 7 \\
6 \cdot 5\end{array}\right\} 5 \cdot 0$ & $\left.\begin{array}{r}8 \cdot 6 \\
8.7 \\
10.0 \\
9 \cdot 0 \\
7.7 \\
10.1 \\
8.1\end{array}\right\}$ & $8 \cdot 9$ \\
\hline D \{ & $\begin{array}{l}19 \\
20 \\
21 \\
22 \\
.23 \\
24\end{array}$ & $\begin{array}{l}16 \cdot 7 \\
16 \cdot 10 \\
17 \cdot 1 \\
17 \cdot 3 \\
17 \cdot 6 \\
17 \cdot 11\end{array}$ & $\begin{array}{l}3 \\
3 \\
3 \\
3 \\
3 \\
3\end{array}$ & $\begin{array}{l}= \\
= \\
= \\
=\end{array}$ & $\left.\begin{array}{l}1 \cdot 9 \\
1 \cdot 4 \\
4 \cdot 1 \\
4 \cdot 4 \\
2 \cdot 2 \\
7 \cdot 7\end{array}\right\} 3 \cdot 6$ & $\left.\begin{array}{l}3 \cdot 6 \\
1 \cdot 0 \\
2 \cdot 3 \\
0 \cdot 6 \\
3 \cdot 1 \\
4 \cdot 1\end{array}\right\} 2 \cdot 5$ & $\left.\begin{array}{l}2 \cdot 0 \\
0.8 \\
1.0 \\
0 \cdot 0 \\
2 \cdot 4 \\
2 \cdot 0\end{array}\right\} 1 \cdot 4$ & $\left.\begin{array}{r}7 \cdot 5 \\
3 \cdot 2 \\
7 \cdot 5 \\
5 \cdot 0 \\
7 \cdot 7 \\
13 \cdot 8\end{array}\right\} 7 \cdot 5$ & $\left.\begin{array}{l}0.7 \\
0.5 \\
0.3 \\
0.7\end{array}\right\} 0.55$ & $\left.\begin{array}{l}1.0 \\
\frac{0.4}{2.3} \\
=\end{array}\right\} 0.55$ & $\left.\begin{array}{r}12 \cdot 4 \\
7.9 \\
9 \cdot 6 \\
6 \cdot 1 \\
14 \cdot 3 \\
10 \cdot 2\end{array}\right\} 10 \cdot 1$ & $\left.\begin{array}{r}11.8 \\
12 \cdot 3 \\
9 \cdot 4 \\
22 \cdot 2 \\
9 \cdot 5\end{array}\right\}$ & $15 \cdot c$ \\
\hline
\end{tabular}

* Age is in years, months. + Sexual development: $1=$ immature; $2=$ partially mature; $3=$ fully mature. $\neq-\bar{c}=$ Not present. $+=$ Plaque approximately 0.5 in. ( $1 \cdot 3$ cm.) diameter. $++=$ Plaque approximately 1 in. $(2.5 \mathrm{~cm}$.) diameter. $+++=$ Plaque approximately 1.5 in. $(3.8 \mathrm{~cm}$.) diameter. The figures after the brackets are the average for that group.

TABLE II.-Average Daily Excretion (mg.) of Individual 17-Ketosteroids by Boys of Various Ages

\begin{tabular}{|c|c|c|c|c|c|c|c|c|c|c|}
\hline $\begin{array}{l}\text { Subject } \\
\text { No. }\end{array}$ & $\begin{array}{c}\text { Age } \\
\text { (Years) }\end{array}$ & $\begin{array}{c}\text { Gynaeco- } \\
\text { mastia }\end{array}$ & $\begin{array}{l}\text { Dehydroepi- } \\
\text { androsterone }\end{array}$ & $\begin{array}{c}\text { Androsterone } \\
\text { (A) }\end{array}$ & $\begin{array}{l}\text { Etiocholano- } \\
\text { lone (E) }\end{array}$ & Keto-A & Keto-E & $11-\mathrm{OH}-\mathrm{A}$ & 11-OH-E & Total \\
\hline $\begin{array}{r}3 \\
7 \\
14 \\
24\end{array}$ & $\begin{array}{l}11 \cdot 6 \\
12 \cdot 10 \\
12 \cdot 10 \\
17 \cdot 11\end{array}$ & $\begin{array}{c}\bar{z} \\
+\bar{t}+\end{array}$ & $\begin{array}{l}0.2 \\
0.4 \\
\mathrm{Nil} \\
0.2\end{array}$ & $\begin{array}{l}0.6 \\
0.7 \\
2.6 \\
2.1\end{array}$ & $\begin{array}{l}0.4 \\
0.2 \\
0.6 \\
5 \cdot 1\end{array}$ & $\begin{array}{l}\mathrm{Nil} \\
\mathrm{Nil} \\
\mathrm{Nil} \\
\mathrm{Nil}\end{array}$ & $\begin{array}{l}0.3 \\
0.2 \\
1.8 \\
0.5\end{array}$ & $\begin{array}{l}0.1 \\
0.1 \\
0.7 \\
0.2\end{array}$ & $\begin{array}{l}\text { Nil } \\
0 \cdot 1 \\
\text { Nil } \\
\text { Nil }\end{array}$ & $\begin{array}{l}1 \cdot 6 \\
1 \cdot 7 \\
5 \cdot 7 \\
8 \cdot 1\end{array}$ \\
\hline
\end{tabular}


course of oestrogen secretion in women during the menstrual cycle, the menopause, lactation, and endocrine ablative procedures. There is the possibility that there are unusual oestrogen metabolites peculiar to the pubertal period which were not detected, but this is thought to be unlikely.

The progressive increases in 17-keto and 17-ketogenic steroids with age correlate well with increasing maturity. The possibility that the gynaecomastia is due to a direct action of increased levels of androgen is unlikely, however, as the condition subsides with the attainment of maturity, when in fact an even higher level of androgen is being secreted.

We suggest that the most likely explanation for the occurrence of gynaecomastia at puberty is that the breast responds to enhanced levels of pituitary hormones, which are responsible for the anatomical and functional changes occurring at that time. The suggestion of Folley (1960), that growth hormone is the most likely active mammotrophic agent, is attractive in view of the fact that its action on the breast is often confined to the stimulation of duct growth, which is the predominant element in gynaecomastia, and that it might be expected to be present in higher concentrations at puberty, when there is an increased rate of body growth generally. The gynaecomastia subsides at the end of puberty, when pituitary activity has diminished.

Mammary hypertrophy may accompany the recovery of sexual potency when the diet is restored to normal after prolonged malnutrition (Klatskin, Salter, and Humm, 1947). This phenomenon may be a consequence of excessive pituitary activity following a period of inhibition and may be likened to a second puberty with the restimulation of testicular function. It would be of the greatest interest to know the steroid excretion of men during refeeding after chronic starvation. It might be expected that they would have intermediate values for $17-\mathrm{KS}$ excretion and low urinary oestrogen concentrations, similar to those found here for pubertal boys.

The local requirement for oestrogen in breast growth is minimal and probably present in all normal individuals of any age. Given this basic steroid environment, duct growth will follow an elevation of the concentration of growth hormone or prolactin. The concentration of oestrogen necessary to stimulate the secretion of prolactin by the pituitary is presumably above that found in normal men, but increase in oestrogen, either by changes in its secretion or by administration, may raise the level to that required.

The hormonal factors which we suggest are usually involved in the control of breast proliferation in the male may therefore be summarized as follows: (1) pre-pubertally the minimum of oestrogen necessary is present but there is insufficient pituitary stimulation and thus no outgrowth; (2) at puberty growthhormone secretion is increased, and, in the presence of the small concentrations of oestrogen already present, causes duct proliferation; (3) at maturity although the level of oestrogen secretion rises it does not reach a level at which prolactin secretion is stimulated-the secretion of growth hormone diminishes, and in the consequent absence of sufficient levels of pituitary hormones there is regression of any breast development ; and (4) with high levels of exogenous or endogenous oestrogen prolactin secretion is stimulated, causing marked mammary growth.

This hypothesis ascribes a functional role to the amount of oestrogen in the normal male.

\section{Summary}

The urinary excretion of oestriol, oestrone, oestradiol, 17-KS, 17-KGS, pregnanediol, and pregnanetriol was studied in prepubertal boys, pubertal boys with and without gynaecomastia, and post-pubertal boys.

The excretion of 17-KS and 17-KGS increased with increasing age and maturity. Oestrogen excretion, however, remained at a low level until full maturity was attained and gynaecomastia, where present, had regressed.

It is concluded that gynaecomastia of puberty is not associated with an increased concentration of oestrogens, but is associated with the increased secretion of pituitary hormones.

We wish to express our thanks to the headmaster and senior biology master and boys of the school, who went to considerable trouble to help us with this work.

\section{REPERENCES}

Brown, J. B., Bulbrook, R. D., and Greenwood, F. C. (1957). F. Endocr., 16,49

Drekter, I. J., Heisler, A., Scism, G. R., Stern, S., Pearson, S., and McGavack, T. H. (1952). F. clin. Endocr., 12, 55 .

Folley, S. J. (1960). Clin. Endocr., 1, 518.

Hall, P. F. (1959). Gynaecomastia. Australasian Medical Publishing Co., Sydney.

Jull, J. W., Shucksmith, H. S., and Bonser, G. M. (1963). F. clin. Endocr., 23, 433.

A. E., and Wade, A. P. (1957). Biochem. F. 66, 196

Klatskin, G., Salter, W. T., and Humm, F. D. (1947). Amer. J. med. Sci., 213, 19.

Leon, Y. A., and Bulbrook, R. D. (1960). F. Endocr., 20, 236.

Norymberski, J. K., Stubbs, R. D., and West, H. F. (1953). Lancet, 1,
1276 .

\title{
Hormone Excretion Studies of Males with Gynaecomastia
}

\author{
J. W. JULL,* PH.D., B.SC. (Leeds)； G. M. BONSER, † M.D., F.R.C.P. ; J. A. DOSSETT, $\ddagger$ M.D.
}

Brit. med. F., 1964, 2, 797-799

Gynaecomastia is encountered clinically in men either as a primary cause for complaint or as a symptom of some fundamental disturbance such as adrenal or testicular tumour. In

- Department of Experimental Pathology and Cancer Research, University of Leeds. Present address: Cancer Research Centre, University of British Columbia, Vancouver 8, Canada.

t Department of Experimental Pathology and Cancer Research, University of Leeds, and Department of Pathology, St. James's Hospital,

‡ Department of Pathology, St. James’s Hospital, Leeds. the preceding report (Jull and Dossett, 1964) evidence was presented that gynaecomastia of puberty was not associated with elevated oestrogen secretion. It was suggested that the cause of the condition is pituitary growth hormone.

From the considerable clinical evidence there can be little doubt that gynaecomastia may also be an accompaniment of conditions in which there is enhanced oestrogen secretion. The following investigations were undertaken to determine the urinary hormone excretion of men with gynaecomastia in an attempt to delineate the hormonal conditions responsible. 